\title{
11
}

\section{Archives, oral traditions and archaeology: Dissonant narratives concerning punitive expeditions on Malakula Island, Vanuatu}

\author{
Stuart Bedford
}

\section{Introduction}

Violent clashes across the islands of the New Hebrides/Nouvelles-Hébrides (Vanuatu since 1980) (Figure 11.1) between Europeans and indigenous populations date from the very first contacts. As was the case for the wider Pacific, clashes related to a multitude of different reasons and motives and were matched by an equally diverse range of reactions and outcomes (e.g. Adams 1984; Douglas 1980; Muckle 2012; Nicole 2011). However, as European empires began to encroach and carve up the wider Pacific in the nineteenth century and their citizens began to settle and proselytise, these clashes became more frequent and increasingly lethal, with a regular naval presence and associated punitive expeditions being initiated in the south-west Pacific from the 1850s. From the 1870s, these expeditions became more frequent and retributive, with a grander scale of military operation in association with more lethal weaponry. It has been argued that these changes were related to the decreasing influence of humanitarianism in society at large from the mid-nineteenth century and it began to be replaced by concerns related more to the primacy of British prestige and reputation, which was served, at least in the south-west Pacific, through demonstrations of naval power (Adams 1984:42-44; Samson 1998:130-147). Other influential factors were also at play. One of these was the increasingly rigid racial stereotyping and the demonising of certain regions, and even specific islands, that had an increasing influence on decisions made by naval commanders and colonial authorities (Bach 1986:47; Samson 1998:7-23).

Naval enforcement, retribution and summary 'justice' constituted standard procedure in the New Hebrides from 1858 and continued for 60 years, with a final naval exercise in 1918 marking the end of major military punitive expeditions (Adams 1984; Bedford 2017; Thompson 1981). Many of the islands of the archipelago experienced some form of punitive expedition at least once, but a number of islands proved to be particularly tenacious in resisting colonial intrusion, mounting effective opposition for generations. Malakula, in the north, was first subject to punitive military expeditions in 1884 but they continued across various areas of the island until 1918 (Bedford 2017). Here the focus is on the 1916 expedition undertaken on the north-east of Malakula by British, French and Australian military personnel, along with auxiliary forces from 
New Guinea, New Caledonia and Efate Island in the central New Hebrides. It was three months in the planning, involved two naval ships and more than 120 heavily armed men who converged on the shore on 3 November. The planned week-long campaign in the interior to destroy a number of villages was a fiasco as it was ambushed and suffered many losses. Subsequently, there were varying claims as to its success or failure and even questions as to whether the correct villages were targeted. Reservations as to the rationality and effectiveness of the government policy of punitive expeditions generally also began to be raised. There are a number of published accounts of the 1916 conflict, but they are almost exclusively based on the official New Hebrides government record. Here, archival records, oral traditions and physical remains relating to various incidents surrounding the 1916 fighting are combined in an attempt to develop a more balanced, unabridged narrative of the whole episode. Ultimately, the research highlights the value of an interdisciplinary approach, but also the complexities involved in determining, in any conflict situation, a detailed and accurate account.
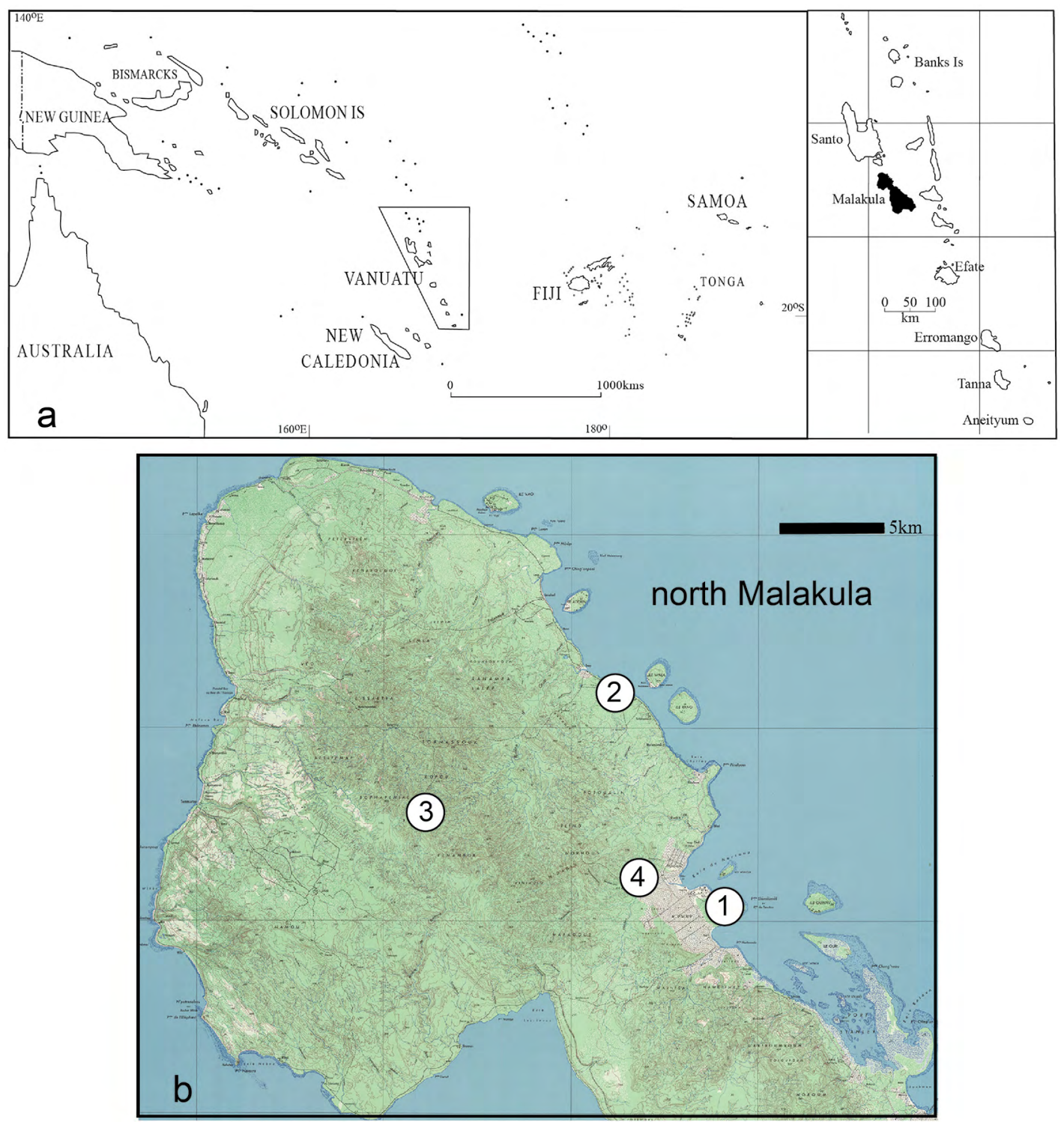

Figure 11.1. A. Southwest Pacific and Vanuatu inset; B. Northern Malakula showing locations of 1. Bridges Store, Tautu; 2. Sanwer beach, landing location; 3. Bartanar village; 4. Mae village. Source: Stuart Bedford. 


\section{Dividing the Pacific}

The eighteenth and nineteenth centuries witnessed a burst of exploratory expeditions across the Pacific sponsored by various European powers. The discovery of new lands and peoples fascinated the ruling and educated elite, but the potential for the extension of empires and accumulation of territory and resources was a major incentive. By the mid-nineteenth century, the latter had become the principal driver of European involvement in the South Pacific, with primarily the British, French and Germans in competition.

The New Hebrides archipelago remained in a state of limbo in terms of formal colonisation until the beginning of the twentieth century, when the French-British Condominium was established in 1906. However, Europeans and other foreigners, with a whole range of different backgrounds and motivations, began arriving on its shores from at least the 1840s. Settlement began in the south, on Tanna and Aneityum, primarily associated with Christian missions and trading and whaling stations. Sandalwood was a major attraction (Shineberg 1967), but arrowroot, copra, coffee and cotton were also early cash crops. From the 1860s, similar settlement began further north on the island of Efate, and then in the 1870s settlers began establishing themselves on Malakula and other islands in the north. Labour recruiting from the late 1860s greatly extended European contact across the entire archipelago (Corris 1970; Docker 1970).

The settlers and missionaries in the New Hebrides were primarily British and French nationals and so it was these two nations that became increasingly involved in the affairs of the archipelago (Scarr 1967:176-217). The respective navies policed the New Hebrides from the 1850s, ostensibly to protect their respective nationals but also to supposedly protect the rights of the indigenous population (Adams 1984; Samson 1998). Despite increasing petitions and enthusiasm from their various colonies (New Caledonia, Australia (Thompson 1980) and New Zealand), neither Britain nor France could agree on outright annexation of the New Hebrides. Rather, they formally agreed in 1878 to recognise their joint spheres of influence while maintaining the archipelago's independence. This arrangement became further formalised in 1887 when the British and French Joint Naval Commission was established. Its role was essentially to police the New Hebrides, protecting their respective nationals and shutting out other colonial powers. Annual naval patrols included joint on-ship meetings, which reviewed disputes as they arose, deciding on what sort of punishment should be dispensed among New Hebridean communities. This often involved the mounting of joint punitive expeditions, as the Naval Commission had neither judicial powers nor facilities suitable for incarceration. The Joint Naval Commission continued even after the establishment of Condominium Government in 1906, as the government had few resources of its own and only a small local police force, said in 1910 to comprise a total of 80 Islanders, mostly Ifira Islanders from Efate and Kanak from New Caledonia (Jacomb 1914). Colonial authorities, initially based only in the capital at Port Vila on Efate, relied primarily on traders, settlers and missionaries for information about what was happening on other islands. Naturally, such individuals were pursuing their own wide range of agendas, and government officials in Port Vila had to sift through a range of often competing correspondence to make decisions from afar that, in the case of the British, were then ultimately forwarded to the Western Pacific High Commissioner based in Fiji, who made final decisions and recommendations to naval commanders after conferring with London. From 1906 these decisions also had to be discussed and agreed on by the French Resident Commissioner, and French government officials in New Caledonia and France. 


\section{Competing for Malakula}

The island of Malakula, located in the north of the Vanuatu archipelago, is the second largest $\left(2000 \mathrm{~km}^{2}\right)$ of the group, comprising a large main island and concentrations of small islands in the north-east, south and south-east. Fertile coastal flats run from the north all the way down the east coast to the southern end of island. The centre of the island and particularly the south are mountainous and valleyed regions. Malakula was the first island in Melanesia visited by Cook in 1774, where he described it (Port Sandwich) as having an excellent harbour. However, European contact was relatively limited up until the 1860s. Labour trafficking brought increased interaction from the 1870s, with Malakula becoming an increasingly favoured destination. The island remained a primary source of labour on plantations within the archipelago even after the official end of the labour trade to Queensland in 1906 (Adams 1986; Cawsey 1998; Docker 1970; Shineberg 1999). Traders began to establish themselves on the island from the 1870s and land speculation was rampant from the early 1880s, with tens of thousands of hectares being secured through a range of dubious means (Bedford et al. 2017; Van Trease 1987). Much of the wide accessible coastal flats of the east coast had been claimed by the end of the nineteenth century. Presbyterian and Catholic missionaries began arriving on the east coast of the island in the late 1880s.

Increasing European intrusion inevitably led to conflict. Labour trafficking was initially the major point of friction, as any form of surveillance was minimal with authorities generally only becoming involved after the reporting of incidents that had interrupted European operations. The investigations and associated decisions regarding punishment initially appeared to be relatively restrained on Malakula. However, with greater European intrusion and visions of greater economic potential to be gained through further ascendancy on the island, primarily through land alienation, the level of conflict intensified significantly. Imperial competition between British and French interests was also in play. Further handicapping government perceptions and ultimately any decisions was a lack of reliable independent information generated from Malakula. There was no government representative on Malakula until 1913, when the French District Agent was established in the far south. Both British and French authorities relied heavily on European residents and missionaries for local intelligence.

\section{Punitive expeditions on Malakula}

The first major punitive expeditions recorded on Malakula were carried out in 1884, independently by French and British naval ships on the north-west and north-east of the island (Bedford 2017; Bedford et al. 2017). They were retributive attacks associated with the killing of labour traffickers and a trader, respectively. Collective guilt was apportioned and retribution, primarily the burning of villages and destruction of crops and animals, was undertaken. Following these initial expeditions there were regular clashes in different parts of Malakula over many decades. The first Joint Naval Commission retaliatory expedition combining British and French forces was in Port Sandwich in the south-east of the island in 1891. Six villages on the northern side of the harbour were destroyed and the associated communities were banned from returning to their traditional lands (Bedford 2017; Bedford et al. 2017).

Following the creation of the Condominium Government in 1906, punitive expeditions became more vengeful and forceful, in attempts to enforce colonial authority and its new regulations. Further complicating the duties of naval commanders from this time was the direction of the Condominium Convention that the Joint Naval Commission should now also intervene directly in indigenous disputes. From this period, explosives were routinely employed to destroy 
standing wooden drums and stone ceremonial structures, along with a new lethal weapon, the Maxim machine gun - using . 303 calibre bullets that could be fired at 600 rounds per minutewhich was standard issue and mainly used to clear intended routes. The wider demonisation of Malakulans also increased from this period. Allegations of their savagery, cannibalistic practices and warlike disposition are made in most publications and reports of the late nineteenth and early twentieth centuries, including regularly in accounts in newspaper reports (e.g. Grimshaw 1907:222; Mawson 1905:415; Rannie 1912:133). During a period of heightened tension and competition for economic resources and social control, this increasingly negative public rhetoric began to influence the colonial and imperial governments and naval authority decisions on how to deal with perceived transgressions.

The early punitive expeditions on the north-east of the island had involved attacks on coastal communities, which were relatively straightforward logistically: villages bombarded from the ship and troops landed to complete the destruction of villages and gardens. However, by the time of the establishment of the Condominium Government in 1906, conflict was being generated with tribal groups located well into the mountainous interior. Increased tensions with tribes in the interior of north-east Malakula date from June 1907. Captain Gaunt, commanding the HMS Cambrian, was ordered to investigate a dispute between two villages, located in the interior of the north-east of the island. Gaunt sent messages ordering the respective villages of Lalip and Bootoomar to meet to discuss the incident. The order was ignored by the latter, which resulted in the mounting of a punitive expedition involving 80 men from the Cambrian. However, the plan went awry early on as the recruited guides appeared to be either unaware of the location of the village or deliberately misleading. The expedition got into an early gunfight in open gardens and suffered a casualty. A Maxim gun was used to clear the area and save the situation. Some of the party then moved on in search of the village, again using the Maxim for track clearance, but after a further two hours among mountainous terrain and no sign of the village, the decision was made to return to camp (Stahlknecht 1907:27). Gaunt was unimpressed by such naval involvement and strategy and suggested that if this was to be future policy then 30-40 men of 'any hill tribe in India' should be supplied to the Resident Commissioner for dealing with such situations on Malakula (Gaunt 1907:44). Other subsequent commanders were to recommend or request contingents of Fijians, Pathans or Buka Islanders.

Serious tensions flared once again in the north-east in 1914. In the interior village of Putermwomo, on 22 February 1914, seven indigenous mission teachers were attacked during an invited visit, resulting in five of them being killed. A punitive expedition was mounted in July 1914 by a Joint Naval force involving 96 men: British, British Native Police, French and French Native Police (Maré Islanders, from New Caledonia) from HMS Torch and the French gunship the Kersaint. The British Resident Commissioner's yacht the HMSY Euphrosyne was also involved, used to transport an advance party of men from the Torch to the small islands off the north-east coast to impound canoes and prevent communication with the interior villages. However, despite having overwhelming superiority in men and weaponry the expedition achieved very little. Malakulans were prepared to sustain some level of destruction of property as they had done repeatedly elsewhere. They abandoned their villages, simply disappearing into the surrounding wild cane where they could take shots at the dispersed expeditionary force spread out along the mountain trails. The futile nature of the mission was summarised by the British Commander in his report: 'It cannot be said that the object of the expedition had been obtained' since no prisoners were taken, 'only pigs and yams of the village were destroyed', and several casualties were sustained (Ward 1914). 


\title{
The expedition of 1916
}

Despite repeated concerns expressed by naval commanders over many years, and particularly in relation to the 1914 expedition, an almost identical and major expedition was mounted in a similar area two years later in November 1916. The punitive expedition of 1916 is one of the few actually mentioned in a number of published texts, often with the facts confused, but always emphasising both the casualties inflicted on the Joint Naval forces and the futility of the whole exercise (Guiart 1952:208-209, 1986:12-13; Harrisson 1937:405-406). This was a remarkable example of imperial obstinance and overreach, particularly considering the stretched military resources at the time. It appears also that little consideration was given to previous experiences in the region. The expedition was sparked by the killing of an Australian trader, Bridges, at Tautu on the north-east coast, along with five children in July 1916. However, it seems very likely that other factors were equally influential. The island continued to be perceived as persistently troublesome and there was also perhaps an element of retribution in association with the failed campaign in 1914 that may have played a role.

The Condominium Government remained handicapped in terms of reliable independent information in the area. In the case of the 1916 killings, and in many earlier incidents in the north of Malakula, they relied heavily on missionaries and Ewan Corlette, an Australian settler who had arrived in north-east Malakula in 1903 soon after having served in the Boer War. He knew the area well and had participated in punitive expeditions on the island since 1906. Tragically, Corlette's son was one of the children killed at Tautu in 1916 as he had been staying with Bridges. The killings occurred on 10 July: Corlette was informed on the 11th and arrived at the scene at $4.30 \mathrm{pm}$ that day. The bodies had already been buried, but he wrote a lengthy, detailed and graphic description of the scene and his interpretation of the sequence of events in a letter dated 12 July and marked as received by the Resident Commissioner in Port Vila on 27 July. The same letter was translated for the French Resident Commissioner and extracts from it had already appeared in regional newspapers by August (Anon. 1916a). Corlette initially suggested 12 men from the bush had been involved who were from the village of Tiragi (Tiragh), claiming (incorrectly) that it was the same village that had been involved in the 1914 killings of local missionary teachers (Corlette 1916a). In a subsequent letter of 8 September, the information was slightly amended, adding further detail but in some respects less clarity on who had carried out the killings:

\begin{abstract}
Although a fairly numerous party of Bushmen went to Tautu only three were concerned in actual killing, the others keeping watch. They all belonged to Tiragi but I am not convinced that there were not some Melandraus men with them. (Corlette 1916b)
\end{abstract}

He also recommended 'a strong expedition, equipped to stay in the bush some time, to teach the natives a salutary lesson' (Corlette 1916b). Motivations for the killings were highly speculative in all reports and mostly put down to facilitating the robbing of the store. However, a report in a New Caledonian newspaper may have been closer to at least providing some background and history that led up to the killings and it also connects at some level to oral traditions. It indicated that Bridges had been warned on many occasions of malicious intent on the part of some locals due to the fact that a man employed by him had died while in his service (Anon. 1916b:15).

Commissioner King had already heard of the killings on 19 July, before Corlette's letter had arrived at the Residency in Port Vila. He left that night on the Euphrosyne to investigate and had the news confirmed when he arrived at Southwest Bay, Malakula, the next day. He then went to Port Stanley and met up with Corlette. In a letter to the High Commissioner in Fiji, King outlined the detail of the killings as recounted by Corlette and gave the same almost verbatim recommendations for a punitive expedition (King 1916a). The recommendations were soon acted upon. The French ship Kersaint was again assigned, with around 30 fighting men, 
mostly Kanaks from New Caledonia who made up the French component of the New Hebrides police. The sourcing of a British ship, however, to join the French was much more challenging. Correspondence between the Resident Commissioner and the Admiralty in London initially emphasised the need for a British ship rather than an Australian one, due to the generally antiFrench sentiment held in Australia regarding the New Hebrides (PRO 1916). However, due to overstretched resources, the British ultimately had to seek support from the newly formed Australian Navy. Admiralty telegrams to Sydney led to further telegrams from Sydney to Rabaul, where the recently commandeered German ship, the Komet, renamed HMAS Una, was assigned the task of joining the French in the attack on Malakula. This expedition marked the first involvement of the Australian Navy and personnel (Figure 11.2) in the New Hebrides, and also included a contingent of 10 Papuans. The expedition was planned as a major campaign to finally pacify this area of Malakula. The village of Bartanar specifically was to be targeted then used as a base to destroy other neighbouring villages. Being aware of the rugged terrain, an expedition of a full week was planned, which involved significant logistical hurdles. Legal hurdles also had to be dealt with. The expedition was to be led overall by Commodore Jackson of the Una and he was duly made a temporary Deputy Commissioner for the Western Pacific on 16 October, as was standard procedure to cover legal concerns (Bickham Escott 1916).

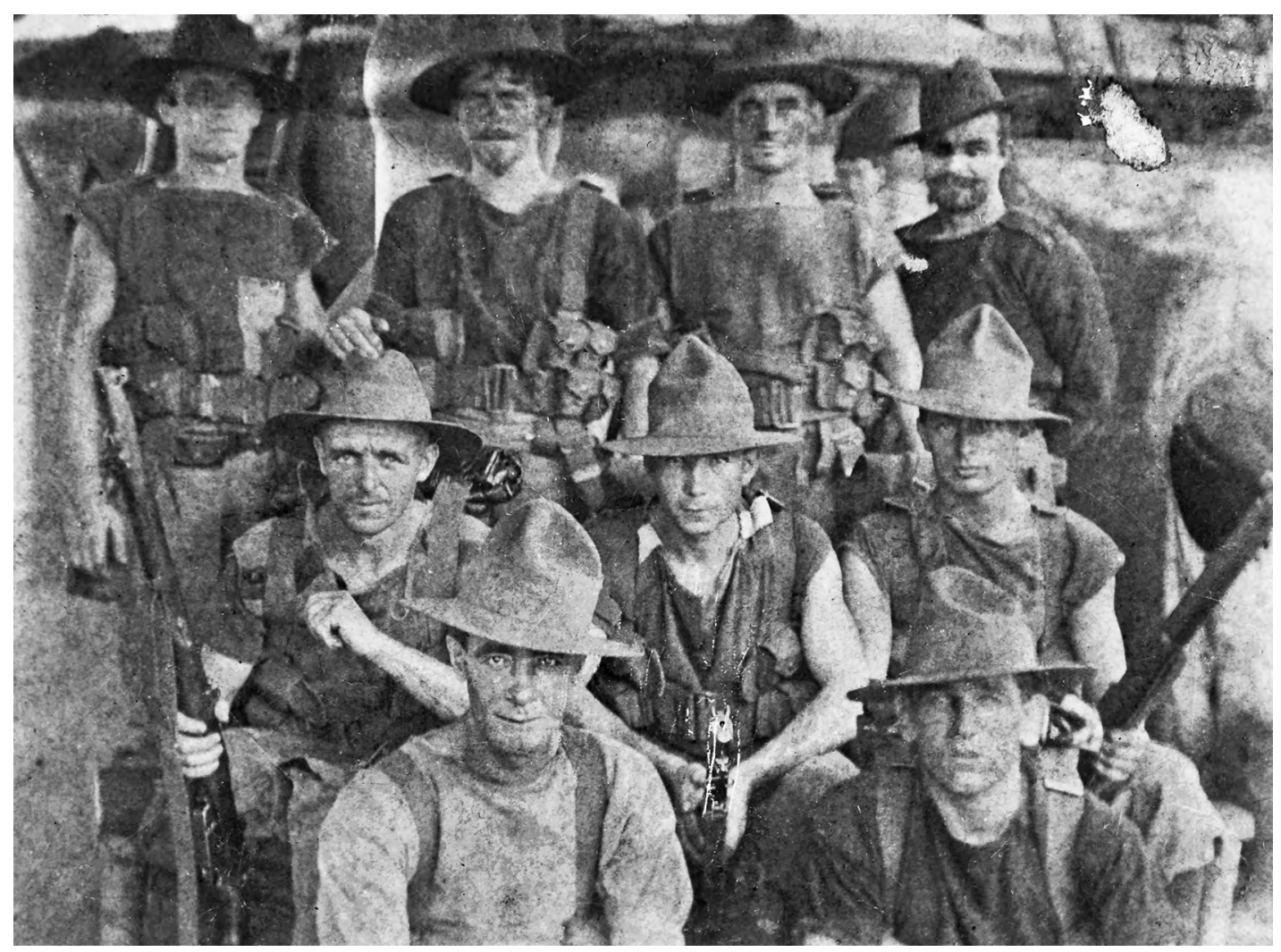

Figure 11.2. Australian troops who had been engaged in the Malakula campaign of 1916.

Source: Australian War Memorial, P00792.001.

The Kersaint and Una met in October 1916 at Havannah Harbour on the west coast of Efate where a suitable area for training in the bush was selected. The training was carried out for a week. The ships then headed up to north-east Malakula on 31 October, arriving in the morning of 1 November. The first task was to blockade the small islands of the north-east so that logistical support could not be provided to villages in the interior. The Euphrosyne, with the Resident Commissioner on board, again played its part. It was to meet with Corlette, secure his participation and find guides and bearers. Once they were recruited, preparations for the week-long campaign were finalised. 
It began on 3 November with the expeditionary force being landed on the beach at Sanwer opposite Wala Island (Figure 11.1b:2) at dawn and heading off with eight days provisions to the village of Bartanar. In an attempt to divert attention from expeditionary activities, the Kersaint was sent at the same time to bombard the west coast of the island (Jackson 1916).

The punitive party reached the outskirts of the village on the evening of the same day, but they decided on an early morning attack. This occurred at 6.00 am the next day with the Papuans leading the charge, although as it was spread among dense bush and rugged terrain, attack was extremely difficult. The village already appeared to be largely empty. In the fighting four men in the village were reported killed but it appears to have been quickly abandoned. Some satisfaction was gained with the immediate burning of the village and killing of pigs. The punitive force had sustained no casualties at this point, but their return to the main camp that had been set up the night before marked the beginning of a humiliating and terrifying retreat. In a repeat of the 1914 expedition the punitive forces appear to have been lured all the way into the interior so that they could then be attacked as they returned along the narrow tracks to their camp and ultimately back down to the beach. Soon after commencing their return the column came under heavy fire from the front and flanks and casualties were sustained. Fighting continued all the way to the main camp with the Malakulans having the advantage of being concealed in the wild cane only yards from the track and being able fire at will. The attacks increased with the column being sniped at from all sides and its progress slowed by the increasing number of casualties. The sniping finally stopped once the column moved beyond the wild cane into open bush and they reached their camp by $2.30 \mathrm{pm}$. Initially it was decided that they would camp the night, although due to the casualties sustained Jackson had already decided to abandon the expedition. Once a local guide suggested that other villages might now join the attack, the night's rest was also cancelled, and a night march was planned. They packed up and left the camp at $8.00 \mathrm{pm}$, leaving behind much of their food supplies. They advanced in single file that stretched over half a mile in length, reaching safer territory by $12.30 \mathrm{am}$. A halt was called due to darkness with the column recommencing its retreat at $4.30 \mathrm{am}$. The shore was reached at $2.00 \mathrm{pm}$ on 5 November and all boarded the ships. As a parting gesture, shelling of the general area of the village by the Kersaint was carried out on the morning of 8 November (Jackson 1916).

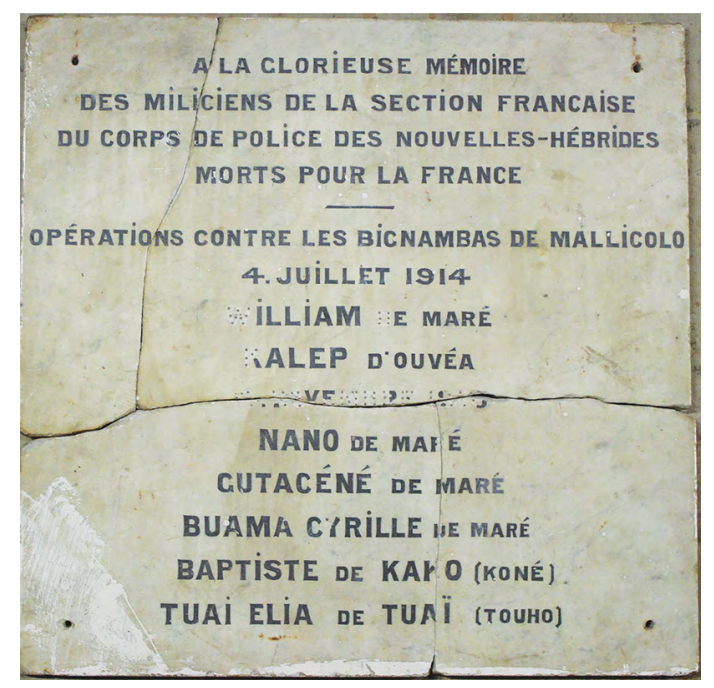

Figure 11.3. Memorial plaque to eight native policemen who had fallen for France on Malakula since 1914. The plaque was bulldozed during roadworks in south Malakula, Vanuatu Cultural Centre, 2015.

Source: Stuart Bedford.
Though the campaign was a complete fiasco, two British reports-the summary account of Jackson, and a letter from Merton King, the Resident Commissioner to the High Commissioner in Fiji-both tried to cast it in positive light. Jackson suggested that the successful attack on and destruction of the village, which had not previously been visited by white men, 'should produce a good moral effect'. He further deemed the loss of a British seaman and eight native policemen (Figure 11.3) as not excessive, considering the eight hours of fighting the column had endured in the wild cane (Jackson 1916). King largely concurred with Jackson, although perhaps deflecting some blame, he added he thought it unlikely that other tribes would have joined the fighting (King 1916b). Others were less congratulatory. Corlette added his thoughts in two letters to the Resident 
Commissioner, outlining the futile nature of the expedition and arguing that another should be organised forthwith. The letters highlight the difficulties for colonial authorities in reaching any considered decisions or subsequent assessments in relation to such situations. Corlette, who was very familiar with the region, had provided the initial detailed intelligence and had participated in the expedition, stated in a letter on 29 December that:

I am convinced that very little harm was done to the natives beyond burning their houses. Other facts I do know from reliable sources are that the village we went to was not that which the murderer's belonged and that they are still defiant and unconquered. (Corlette 1916c)

In a later letter of June 1917, urging further action, he states:

I have nothing too definite to report concerning the result of the punitive expedition but had heard rumours that confirm my own conviction as to its futility. It is now said that none of the shells fired by the French warship burst, which is a direct contradiction of the earlier rumours. (Corlette 1917)

However, despite this plea the punitive expedition of 1916 marked the last major colonial military action in the north-east area of Malakula.

\section{Contemporary indigenous narratives}

Apart from regular sensationalist newspaper reports, published accounts of the many punitive expeditions in the New Hebrides are relatively few. They are primarily gleaned from European historical resources and are largely restricted to the earliest clashes on Tanna (Adams 1984) and the 1916 Malakula expedition (Guiart 1952:208-209, see Bedford 2017). There is a large archival record housed across the globe relating to this colonial-period violence, in English, French and German, which awaits detailed analysis and wider publicity. However, what is really missing to date is the voices or accounts of the descendants of those groups who clashed with the imperial and colonial forces. Attempts to explicitly connect with the physical remains of these events in Vanuatu have also been absent to date.

An opportunity to redress these aspects developed out of an Australian Research Council project (FT120100716) to record stone ceremonial structures (nasara) (Deacon 1934; Layard 1942) across the Malakula landscape (Bedford et al. 2017). The recording of associated stories with many of the sites was a key component of the project and, having been made aware of the numerous punitive raids in various areas, attempts were made to seek out those sites specifically, along with the communities that were directly connected and descendants of those who had been impacted. With the passing of time, more than 100 years in most cases, coupled with disruption through extensive depopulation and land alienation, it is not surprising that in many cases details and dates of various punitive conflicts had begun to fade or had been conflated or substantially augmented. In almost all cases though, at least among the older generations, some memories were retained and most of those were commonly recorded in song (all stories and songs relating to conflict with imperial and colonial forces were recorded and are now held by the Film and Sound Archive Unit at the Vanuatu Cultural Centre). The 1916 conflict stood out in many respects in that it appeared to remain very vivid in the memory of the Tiragh tribe, the majority of which has been long based at the mission-established village of Mae, very distant from traditional lands (Figure 11.1b:4). Its relatively recent date may have contributed, with apparently many of the combatants still alive in the 1960s and into the 1970s, and who may well have been eager to recount, at least from their perspective, a victory against all odds.

The Vanuatu Cultural Centre fieldworker from Mae village, Massing Tamendal, was key to unlocking an indigenous perspective to the 1916 conflict. Vanuatu Cultural Centre Fieldworkers (filwokas) are volunteer representatives spread throughout the country who promote and preserve 
custom and culture. I was aware of the connections of Mae villagers with Bartanar and the 1916 fighting and an opportunity arose while on other fieldwork in 2014 to ask Massing whether he was aware of these events. Immediately he responded in the positive, saying that: 'yes indeed it was us who killed Bridges and fought the white men'. In September 2016, almost 100 years after the punitive expedition, we retraced events and visited associated sites with an enthusiastic group of young and old from Mae village. We started at Tautu on the coast, where Bridges' trading station had been based. It was here that a local version of the lead-up to the killing of Bridges and the children emerged. It was recounted that some time before the killings a group of Tiragh men had sought paid work from Bridges. The task assigned was the digging of a large well, located near the store, through the hard uplifted reef (the remains of the c. $3 \mathrm{~m}$ diameter uncompleted well can still be seen today). The men toiled for some days before returning to their village, but as they had not completed the work, they returned without any remuneration. This apparently enraged their chief, who instructed them to return to Bridges and seek some form of payment. No further detail could be provided as to what transpired at the store with Bridges and what ultimately led to the killings, although the incident is recorded in customary song.

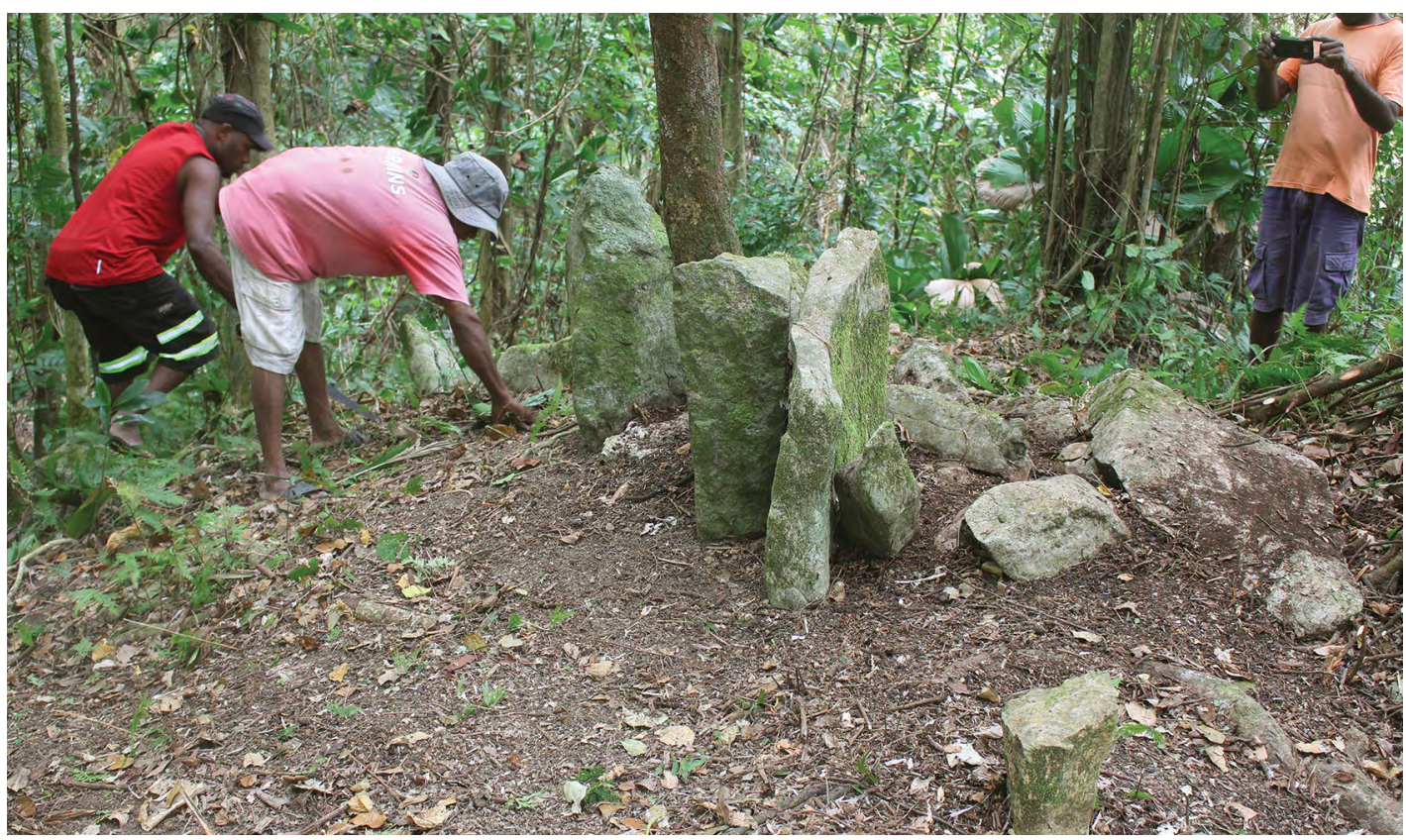

Figure 11.4. Remnant standing stones, Bartanar nasara, north Malakula, 2016.

Source: Stuart Bedford.

On completion of the coastal visit we headed to Bartanar in the interior. After some kilometres on the back of a truck and then almost four hours walking, we reached the former village and associated nasara, defined by a series of standing stones (Figure 11.4). Most of the people in the group had never visited the site; even the older men of the group seemed initially confused as to its location, having not visited the site since their youth. It was impressive in its apparent isolation and elevation (Figure 11.1b:3), the strategic location and terrain immediately highlighting the challenges faced by any invading party. There was very limited knowledge in relation to the actual fighting at the site, apart from the fact that it did occur, and that houses were burnt, pigs killed and gardens spoiled. It was claimed that there had been no casualties. Nearby, we visited a number of other nasara sites associated with former villages that were said to have participated in the fighting of 1916. The Tiragh are a tribal entity that once encompassed many villages in the area rather than any single settlement and many of the neighbouring villages had familial and customary ties to Bartanar that obligated those communities to join in the combat. A large pit feature was also visited (Figure 11.5), and this was identified as having been the result of naval shelling. All confirmed that 
no damage had been inflicted by the shelling but chunks of iron had been later salvaged from the pit and subsequently used as very effective heat retainers in earth ovens. Although not definitively associated with the 1916 campaign, during separate surveys in interior areas nearby, sections of naval shells that had been collected and curated were identified (Figure 11.6).

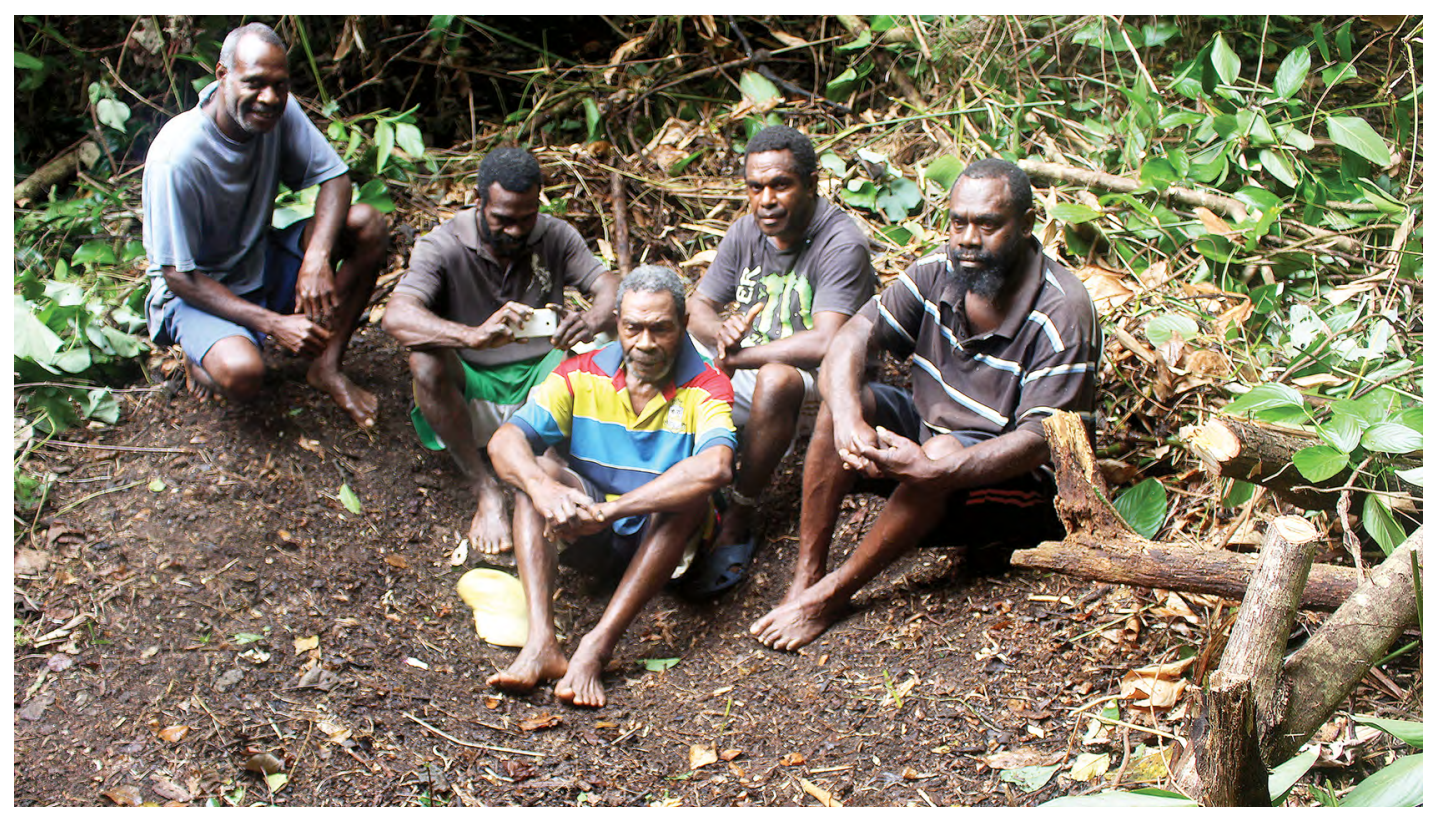

Figure 11.5. Large impression said to be due to the result of naval shelling. Massing Tamendal (far left) and Chief Liten (second from right), 2016.

Source: Stuart Bedford.
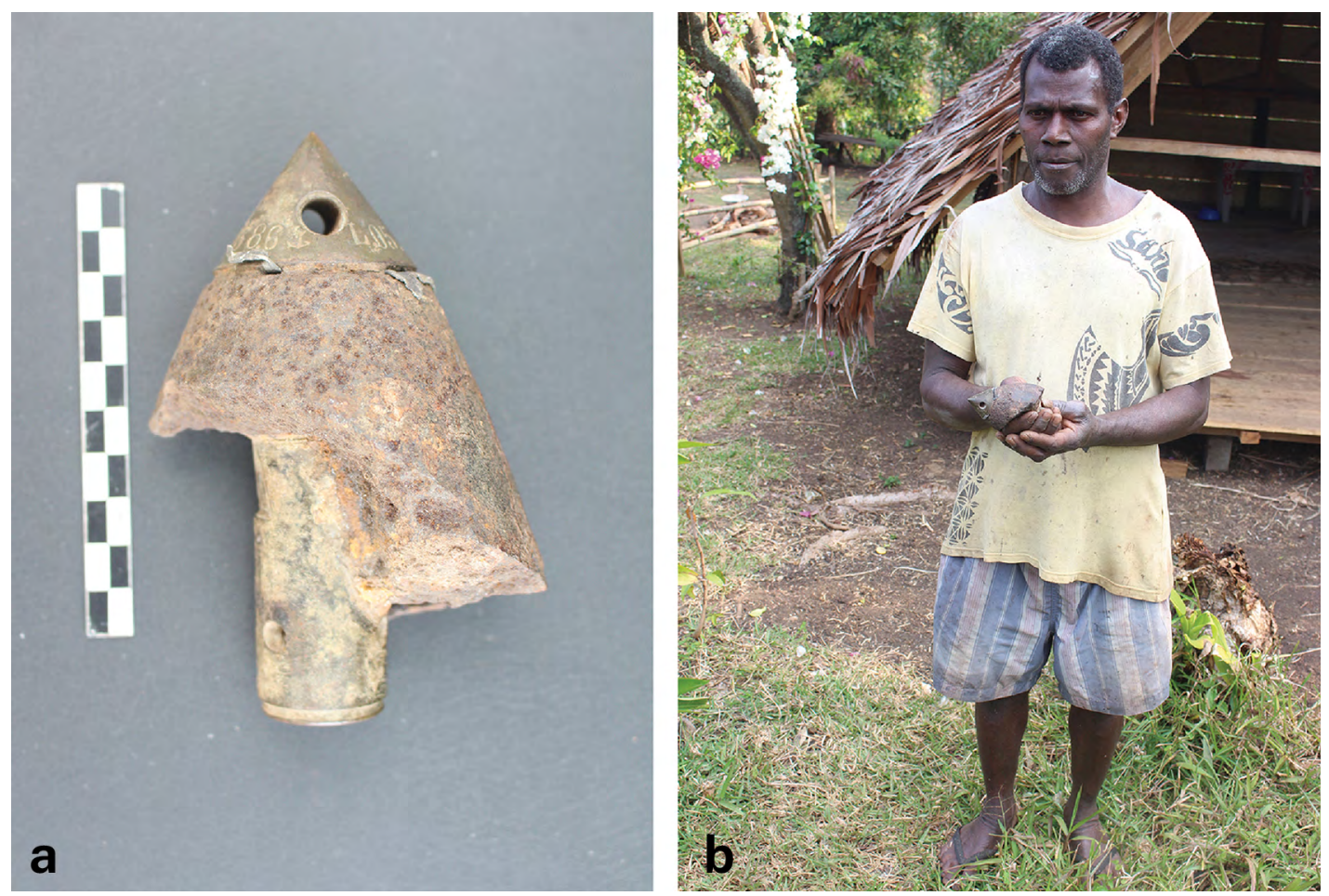

Figure 11.6. A. Fragment of 4-inch naval shell (inscribed on the nose: 1.05.No4.M.83164.7.158.6워); B. Same shell fragment held by André Ralle, Peterpu village, north Malakula, 2015.

Source: Stuart Bedford. 


\section{Discussion}

Attempts to understand the influences, decisions, strategies, events and personalities that were involved in the November 1916 clash on Malakula, using a range of sources, has clarified a number of aspects but has also uncovered, among those same sources, some level of dissonance. It would be surprising if it hadn't, considering the nature of the historical information and the time depth and disruption that has occurred among local communities since 1916. It was confirmed that men from Bartanar had been involved in the killing of Bridges and the children and that Bartanar had been subsequently the focus of a punitive expedition. Men from other villages were also involved in the fighting. Naval shells had been fired and apparently did explode in some cases. Both sides claimed some level of satisfaction: descendants of those from Bartanar said that no lives had been lost; while colonial and naval authorities accepted losses as inevitable, but thought that appropriate punishment had been administered. In constructing a post-conflict narrative all parties were no doubt playing to their respective wider audiences in order to justify their actions and assert their moral authority.

Colonial strategy in 1916 followed a well-worn pattern of assembling overwhelming numbers of armed men with superior weaponry to destroy settlements and gardens of entire communities. There was always an assumed level of strategic and technological superiority among Europeans, but it was often effectively nullified by the terrain and Malakulan tactics. Settlements could be quickly abandoned and fighters could lay in wait and attack as opportunities arose. While many facets of this conflict will forever remain in the realm of speculation, archaeology has potentially a key role to play in elucidating further detail of colonial-period conflicts such as these at a whole series of levels from a neutral perspective. The archaeological component of this study was superficial, involving only surface survey, but if excavation and geophysical investigations were undertaken across the wider area they would greatly enhance understanding of this conflict landscape.

Colonial violence is an integral component of the fabric of almost all Pacific Island nations and in some areas aspects of these clashes have been addressed in various detail by historians over the past 40 years (e.g. Belich 1986; Douglas 1980; Hempenstall 1978; Keesing and Corris 1980; Muckle 2012; Nicole 2011; Sack 2001). However, while conflict archaeology is a global trend (Scott and McFeaters 2011), it has yet to be engaged to any great extent in the Pacific.

Even in New Zealand, a nation forged through colonial violence, where pioneering excavations associated with the Land Wars were undertaken as early as the late 1970s, the research focus remains insipid (Prickett 1992, 2016). The need for greatly increased archaeological input into the New Zealand Wars has been emphasised by Professor James Belich, the pre-eminent historian of the subject (Crawford and McGibbon 2018:13). In Vanuatu, colonial-period violence remains strikingly under-researched by all academic disciplines. General histories relate a standard tale from the arrival of the early European explorers, sandalwood and labour traders, missionaries, resident traders and the Condominium Government through to the lead-up and struggle for independence in the 1970s. Serious indigenous opposition to colonial encroachment and associated colonial reactions in the nineteenth and early twentieth centuries are largely absent. This period of sustained opposition, which took many forms and occurred across much of the archipelago, remains largely excluded from contemporary historical narratives and public consciousness in Vanuatu today. Such histories can be complex, disturbing and often sensitive, but increasing the focus on colonial-period violence in the Pacific has the potential to contribute to a more balanced understanding of the legacy of colonialism in the region. More importantly for present-day communities, it may go some way toward resolving contemporary struggles over land, resources and identity across the region (Bedford et al. 2017; Flexner et al. 2016; Spriggs 1997:286-291). 


\section{Acknowledgements}

Massing Tamendal, resident of Mae village and fieldworker for the Vanuatu Cultural Centre, was instrumental in facilitating the visit to Bartanar and the recording of oral traditions related to the conflict. Chief Eloi Liten of Dakel village guided us to other surrounding village sites associated with people who had also participated in the fighting of 1916. He also hosted our substantial group at Dakel village. I thank Stephen Innes and colleagues at Special Collections, University of Auckland Library, for their help and permission to conduct research among the Western Pacific High Commission records and to reference and reproduce information from various files. An Australian Research Council Future Fellowship (FT120100716) funded archival research and fieldwork on Malakula.

\section{References}

Adams, R. 1984. In the land of strangers. A century of European contact with Tanna, 1774-1874. Pacific Research Monograph No. 9. The Australian National University, Canberra.

Adams, R. 1986. Indentured labour and the development of plantations in Vanuatu: 1867-1922. Journal de la Société des Océanistes 42:41-63. doi.org/10.3406/jso.1986.2822.

Anon. 1916a. Island tragedy. Killed by Cannibals. Trader and children. Sydney Morning Herald, 22 August.

Anon. 1916b. Massacre d'une famille anglaise. Aux Nouvelles-Hebrides. Le Bulletin du Commerce, August.

Bach, J. 1986. The Australia station: A history of the Royal Navy in the South West Pacific, 1821-1913. NSW University Press, Sydney.

Bedford, S. 2017. 'A good moral effect?': Local opposition and colonial persistence in Malakula, New Hebrides, 1875-1918. Journal of Colonialism and Colonial History 18(1). doi.org/10.1353/cch.2017. 0003 .

Bedford, S., M. Abong, R. Shing and F. Valentin 2017. From first encounters to sustained engagement and alienation: European and ni-Vanuatu contact from 1774 to 1915, Port Sandwich, Malakula, Vanuatu, Southwest Pacific. In M. Cruz Berrocal and C.-h. Tsang (eds), Historical archaeology of early modern Colonialism in Asia-Pacific, pp. 92-112. Volume 1. University Press of Florida, Gainesville. doi.org/10.5744/florida/9780813054759.003.0005.

Belich, J. 1986. The New Zealand Wars and the Victorian interpretation of racial conflict. Auckland University Press, Auckland.

Bickham Escott, E. 1916. Letter from High Commissioner Bickham Escott to Commodore Jackson appointing him as temporary Deputy Commissioner for the Western Pacific (WPHC 2693/16). AU Microfilm 78-326. Records of the Western Pacific High Commission. Special Collections, University of Auckland.

Cawsey, K. 1998. The making of a rebel: Captain Donald Macleod of the New Hebrides. Institute of Pacific Studies, Suva.

Corlette, E. 1916a. Letter from Ewan Corlette to Resident Commissioner Merton King, 12 July 1916. New Hebrides British Service (NHBS 32/16). Records of the Western Pacific High Commission. Special Collections, University of Auckland.

Corlette, E. 1916b. Letter from Ewan Corlette to Resident Commissioner Merton King, 8 September 1916. New Hebrides British Service (NHBS 32/16). Records of the Western Pacific High Commission. Special Collections, University of Auckland. 
Corlette, E. 1916c. Letter from Ewan Corlette to Resident Commissioner Merton King, 29 December 1916. New Hebrides British Service (NHBS 32/16). Records of the Western Pacific High Commission. Special Collections, University of Auckland.

Corlette, E. 1917. Letter from Ewan Corlette to Resident Commissioner Merton King, 19 June 1917. New Hebrides British Service (NHBS 32/16). Records of the Western Pacific High Commission. Special Collections, University of Auckland.

Corris, P. 1970. Pacific Island labour migrants in Queensland. Journal of Pacific History 5:43-64. doi.org/ $10.1080 / 00223347008572164$.

Crawford, J. and I. McGibbon 2018. Introduction. In J. Crawford and I. McGibbon (eds), Tutu Te Puehu: New perspectives on the New Zealand Wars, pp. 11-14. Steele Roberts Aotearoa, Wellington.

Deacon, B. 1934. Malekula: A vanishing people in the New Hebrides. Routledge and Sons, London.

Docker, E. 1970. The Blackbirders: The recruiting of South Seas labour for Queensland, 1863-1907. Angus and Robertson, Sydney.

Douglas, B. 1980. Conflict and alliance in a colonial context: Case studies in New Caledonia, 1853-1870. Journal of Pacific History 15(1):21-51. doi.org/10.1080/00223348008572386.

Flexner, J., M. Spriggs, S. Bedford and M. Abong 2016. Beginning historical archaeology in Vanuatu: Recent projects on the archaeology of Spanish, French, and Anglophone Colonialism. In S. MontónSubías, M. Berrocal and A. Martínez (eds), Archaeologies of early modern Spanish Colonialism, pp. 205-222. Springer International, Switzerland. doi.org/10.1007/978-3-319-21885-4_9.

Gaunt, E. 1907. Gaunt to Commander-in-Chief, 6 July 1907 (WPHC 8/II 3026869/28). Royal Navy Australia Station, New Hebrides Report. Records of the Western Pacific High Commission. Special Collections, University of Auckland.

Grimshaw, B. 1907. From Fiji to the Cannibal Islands. Eveleigh Nash, London.

Guiart, J. 1952. L'organisation sociale et politique du Nord Malekula. Journal de la Société des Océanistes 8:208-209. doi.org/10.3406/jso.1952.1740.

Guiart, J. 1986. La conquête et le déclin: Les plantations, cadre des relations sociales et économiques au Vanuatu (ex Nouvelles-Hébrides). Journal de la Société des Océanistes 82-83:7-40. doi.org/10.3406/ jso.1986.2821.

Harrisson, T. 1937. Savage civilisation. Victor Gollancz, London.

Hempenstall, P. 1978. Pacific Islanders under German Rule: A study in the meaning of colonial resistance. Australian National University Press, Canberra. doi.org/10.26530/oapen_612753.

Jackson, J. 1916. Report to the Secretary of the Admiralty on the punitive expedition to Malekula (WPHC 3307/16). AU Microfilm 78-326. New Hebrides British Service, Records of the Western Pacific High Commission. Special Collections, University of Auckland.

Jacomb, E. 1914. France and England in the New Hebrides: The Anglo-French condominium. G. Robertson, Melbourne.

Keesing, R. and P. Corris 1980. Lightning meets the west wind: The Malaita massacre. Oxford University Press, Melbourne.

King, M. 1916a. Letter from Resident Commissioner King, New Hebrides, to High Commissioner Bickham Escott, 28 July 1916. Malakula Punitive Expedition, New Hebrides, 1914-1916. Admiralty Records, 8387/225. Public Records Office, London. 
King, M. 1916b. Resident Commissioner King, New Hebrides, to High Commissioner Bickham Escott, 20 November 1916, Forwards, with comments, Commander Jackson's report on the punitive expedition to Malekula (WPHC 3307/16). AU Microfilm 78-326. New Hebrides British Service, Records of the Western Pacific High Commission. Special Collections, University of Auckland.

Layard, J. 1942. The stone men of Malakula: The small island of Vao. Chatto and Windus, London.

Mawson, D. 1905. The geology of the New Hebrides. Proceedings of the Linnean Society of New South Wales 3:400-485. doi.org/10.5962/bhl.part.12911.

Muckle, A. 2012. Spectres of violence in a Colonial context: New Caledonia 1917. University of Hawai' $\mathrm{i}$ Press, Honolulu.

Nicole, R. 2011. Disturbing history: Resistance in early colonial Fiji. University of Hawai i Press, Honolulu.

Prickett, N. 1992. The archaeology of the New Zealand Wars. Australasian Historical Archaeology 10:3-14.

Prickett, N. 2016. Fortifications of the New Zealand Wars. New Zealand Department of Conservation Te Papa Atawahi, Wellington.

PRO 1916. Malakula Punitive Expedition, New Hebrides, 1914-1916. Admiralty Records, 8387/225. Public Records Office, London.

Rannie, D. 1912. My adventures among South Sea Cannibals. Seeley, Service \& Co., London.

Sack, P. 2001. Phantom history, the rule of law and the colonial state: The case of German New Guinea. The Australian National University, Canberra.

Samson, J. 1998. Imperial benevolence: Making British authority in the Pacific Islands. University of Hawail $\mathrm{i}$ Press, Honolulu. doi.org/10.1515/9780824862947.

Scarr, D. 1967. Fragments of empire: A history of the Western Pacific High Commission 1877-1914. Australian National University Press, Canberra.

Scott, D. and A. McFeaters 2011. The archaeology of historic battlefields: A history and theoretical development in conflict archaeology. Journal of Archaeological Research 19(1):103-132. doi.org/ 10.1007/s10814-010-9044-8.

Shineberg, D. 1967. They came for sandalwood: A study of the sandalwood trade in the South-West Pacific 1830-1865. Melbourne University Press, Melbourne.

Shineburg, D. 1999. The people trade: Pacific Island laborers and New Caledonia, 1865-1930. University of Hawai'i Press, Honolulu. doi.org/10.1515/9780824864910.

Spriggs, M. 1997. The Island Melanesians. Blackwell, Oxford.

Stahlknecht, 1907. Lieutenant Stahlknecht to Captain Gaunt, 1 July 1907 (WPHC 8/II 3026869/28). Royal Navy Australia Station, New Hebrides Report. Records of the Western Pacific High Commission. Special Collections, University of Auckland.

Thompson, R. 1980. Australian imperialism in the Pacific: The expansionist era 1820-1920. Melbourne University Press, Melbourne.

Thompson, R. 1981. Natives and settlers on the New Hebrides frontier 1870-1900. Pacific Studies 5(1):1-18.

Van Trease, H. 1987. The politics of land in Vanuatu. University of the South Pacific Press, Suva.

Ward, J. 1914. Report on the expedition to Putermwomo, Malekula Island. HMS Torch at sea, 6 July 1914 (WPHC 1891/14) New Hebrides British Service, Records of the Western Pacific High Commission. Special Collections, University of Auckland. 
This text is taken from Archaeological Perspectives on Conflict and Warfare in Australia and the Pacific, edited by Geoffrey Clark and Mirani Litster, published 2022 by ANU Press, The Australian National University, Canberra, Australia.

doi.org/10.22459/TA54.2021.11 